IZA DP No. 6067

Combating In-Work Poverty in Continental Europe: An Investigation Using the Belgian Case

Ive Marx

Josefine Vanhille

Gerlinde Verbist

October 2011 


\title{
Combating In-Work Poverty in Continental Europe: An Investigation Using the Belgian Case
}

\author{
Ive Marx \\ University of Antwerp \\ and IZA \\ Josefine Vanhille \\ University of Antwerp
}

Gerlinde Verbist

University of Antwerp

Discussion Paper No. 6067

October 2011

\author{
IZA \\ P.O. Box 7240 \\ 53072 Bonn \\ Germany \\ Phone: +49-228-3894-0 \\ Fax: +49-228-3894-180 \\ E-mail: iza@iza.org
}

\begin{abstract}
Any opinions expressed here are those of the author(s) and not those of IZA. Research published in this series may include views on policy, but the institute itself takes no institutional policy positions.

The Institute for the Study of Labor (IZA) in Bonn is a local and virtual international research center and a place of communication between science, politics and business. IZA is an independent nonprofit organization supported by Deutsche Post Foundation. The center is associated with the University of Bonn and offers a stimulating research environment through its international network, workshops and conferences, data service, project support, research visits and doctoral program. IZA engages in (i) original and internationally competitive research in all fields of labor economics, (ii) development of policy concepts, and (iii) dissemination of research results and concepts to the interested public.
\end{abstract}

IZA Discussion Papers often represent preliminary work and are circulated to encourage discussion. Citation of such a paper should account for its provisional character. A revised version may be available directly from the author. 
IZA Discussion Paper No. 6067

October 2011

\title{
ABSTRACT
}

\section{Combating In-Work Poverty in Continental Europe: An Investigation Using the Belgian Case}

\begin{abstract}
Recent studies find in-work poverty to be a pan-European phenomenon. Yet in-work poverty has come to the fore as a policy issue only recently in most continental European countries. Policies implemented in the United States and the United Kingdom, most notably in-work benefit schemes, are much discussed. This article argues that if it comes to preventing and alleviating poverty among workers, both the policy options and constraints facing Continental European policymakers are fundamentally different from those facing Anglo-Saxon policymakers. Consequently, policies that work in one setting cannot be simply emulated elsewhere. We present micro-simulation derived results for Belgium to illustrate some of these points. Policy options discussed and simulated include: higher minimum wages, reductions in employee social security contributions, tax relief for low-paid workers, and the implementation of a stylised version of the British Working Tax Credit. The latter measure has the strongest impact on in-work poverty but in settings where wages are compressed, as in Belgium, a severe trade-off between coverage and budgetary cost presents itself. The article concludes that looking beyond targeted measures to universal benefits and support for employment of carers may be important components of an overall policy package to tackle in-work poverty.
\end{abstract}

JEL Classification: $\quad$ I32, J21, R28, J68

Keywords: in-work poverty, low pay, in-work benefits, negative income taxes

Corresponding author:

Ive Marx

Centre for Social Policy

University of Antwerp

St Jacobstraat 2

2000 Antwerpen

Belgium

E-mail: ive.marx@ua.ac.be 


\section{Introduction}

Combating in-work poverty is an issue that affects all of Europe, including the countries where the fight against unemployment and poverty out of work remains the bigger challenge (Andre $\beta$ and Lohmann, 2008; OECD, 2009; Eurofound, 2010). There already exists a substantial literature on policies to combat in-work poverty in Anglo-Saxon countries, in part because of a longer standing awareness about this issue. In the United States, the 1993 expansion of the Earned Income Tax Credit (EITC) turned it into the country's pre-eminent anti-poverty program for families of working age. The EITC, in combination with other policy reforms and several increases in the minimum wage, produced some striking results, including marked increases in labour market participation and declines in poverty among some segments of the population, especially single-parent households (Hotz and Scholz, 2003; Eissa and Hoynes, 2004).

The United Kingdom has also implemented and extended several schemes, culminating in the Working Tax Credit (WTC) of 2003 (Brewer et al., 2006). Elsewhere in Europe, concern for the 'working poor' has emerged as a policy issue only recently. The policy solutions implemented in the United States and the United Kingdom garner considerable interest. Several European countries have contemplated introducing Anglo-Saxon-style tax credits, or are presently doing so. Interestingly, some countries have already backed away from the idea or implemented a watered-down version, perhaps to show their commitment to 'Third Way' or 'Active Welfare State' ideas. Examples here include the 'Prime Pour l'Emploi' (PPE) and the Revenue de Solidarite Active (rSa) in France, the 'Combination Credit' in the Netherlands, and a "Low Wage Tax Credit" in Belgium (Marx and Verbist, 2008a). As we will illustrate for Belgium in some detail, the Belgian tax credit only exhibits a faint resemblance to the EITC or the WTC. This is also the case for the French and Dutch schemes. The UK Working Tax Credit, to be replaced by the Universal Credit, remains the most important measure of its kind in Europe, both in terms of scope and budget. Interest remains strong, in the public debate and in the academic literature (Kenworthy, 2011).

This brings us to the core theme of this article. When it comes to preventing and alleviating poverty among workers, both the policy options and constraints facing Continental European policymakers are different from those facing Anglo-Saxon policymakers. To start with, effective minimum wages are, generally speaking, already comparatively high relative to median wages, suggesting a more limited scope for policy action on this front. At the same time, taxes and social security contributions are more significant in many Continental European countries, making it more likely that workers are 'taxed into poverty'. The potential scope for improving worker's living standard through tax relief and reductions in social security contributions may be more substantial for that reason.

The political and governance constraints are also fundamentally different in the predominantly Bismarckian Continental European settings (Palier, 2010; Streeck, 2009). Within Bismarckian social protection systems there are specific limits to the extent to which 
need-based elements can be introduced. While, for example, targeted social contribution reductions may make sense from a poverty reduction viewpoint, the primacy of the contributory and equivalence principles may limit the extent to which this is feasible. And while social policy is predominantly government controlled in the Anglo-Saxon countries, allowing for coordination with tax and other income policies (like minimum wages), social security and wage setting remain largely the prerogative of the social partners in Continental Europe. This implies that the coordination of wage, social transfer and tax policies may be more difficult and that poverty alleviation has to be reconciled with other considerations and interests.

This article considers the specific policy issues in relation to combating in-work poverty in Continental Europe. Specifically, this article will look at what higher minimum wages and (targeted) tax reductions can do to reduce in-work poverty. It also considers the potential impact of a UK-style tax credit. A general discussion is complemented with microsimulation analyses for Belgium that serve to illustrate the points made.

Belgium represents an interesting case for a number of reasons. First, and as we will document in more detail below, Belgium has one of the lowest in-work poverty rates in the European Union with around 5 per cent of workers living in financial poverty in 2008, relative to the 60 per cent of median equivalent household income threshold. Nevertheless, inwork poverty accounts for about a third of the population at working age living in poverty. Around 50 per cent of working poor households are households with children.

Belgium also has a comparatively compressed wage structure. According to the OECD's data base on earnings, Belgium has just about the lowest incidence of relatively low-paid work in the OECD area (OECD, 2010). Less than 6 per cent of Belgium's workers earn less than 67 per cent of median earnings. The OECD26 average is 16 per cent. At the same time, taxes and social security contributions on wages are on the highest side of spectrum (Immervoll, 2007). In that sense, it combines two contextual features that make many of the Continental European welfare states substantially different from the Anglo-Saxon countries that have received significantly more attention in the literature. That is not to say that Belgium is a 'typical' Continental European case. While low-paid work is less prevalent in countries like Belgium or France, Germany is a case where low-paid work is as frequent, relatively speaking, as in the United Kingdom or Ireland. In Poland and some of the Baltic countries it appears to be even more widespread. Similarly, in terms of the overall tax burden put on workers, including social security contributions, the picture across Continental Europe is actually quite varied. What makes Belgium interesting, we would argue, is that on two key dimensions - wage compression and taxation - it is at the extreme end of the spectrum and for that reason particularly worth looking at.

The article starts with a discussion of the data, definitions and methods. It continues with a brief sketch of the extent and specific nature of in-work poverty in Continental European welfare states and in Belgium in particular. The focus then turns to an examination of alternative policy options: a) raising minimum wages and effective wage floors; $b$ ) reductions 
in personal income taxes and social security contributions for low wage workers and c) the introduction of the UK-style tax credit. A final section discusses the key elements of a suitable policy mix for combating in-work poverty in Continental Europe.

\section{Data and methods}

For this paper we use EU-SILC for 2006 to identify those in work the previous year, and living in a household with a total disposable household income below the commonly used 60 per cent of median equivalent income threshold, using the OECD modified equivalence scale. ${ }^{1}$ We use microsimulation modelling for the empirical assessment of policy options in Belgium. This technique is particularly well-suited to investigate the consequences of policy changes as these interact with the existing tax-benefit structure. The method has already been used to study the impact of alternative policies for combating in-work poverty (see e.g. Sutherland (2001) for the U.K., Müller and Steiner (2008) for Germany, Figari (2009) for Southern European countries, Formby et al. (2010) for the U.S.).

We use the microsimulation model MISIM (see Verbist, 2003). MISIM (MicroSImulationModel) is a static tax-benefit model designed to evaluate policy alternatives in the field of social security and personal income taxation. The model covers personal income taxes, social security contributions and part of social benefits. MISIM can provide as output both the budgetary consequences of policy measures as well as the impact on the income distribution and poverty.

Simulation models have some inherent limitations. This method uses empirical data that are either obtained by means of surveys or from administrative sources. As such, the accuracy of the results depends on the quality of the data (e.g. adequate information about the relevant socio-economic characteristics, a sufficiently large sample). Our model runs on the Belgian EU-SILC 2006 survey data for a representative sample of the Belgian population. We use the Belgian version rather than the uniformed EUROSTAT version, because it contains a number of more detailed variables required to simulate the tax-benefit system accurately. Apart from socio-economic characteristics corresponding to the moment of the interview (2006), EUSILC-2006 captures incomes and income-relevant variables such as labour market status for the entire year 2005. As a consequence, the presented figures pertain to the Belgian situation in 2005. While in a number of countries concern has been raised about the data quality of the EU-SILC (see e.g. Hauser, 2008), the available evidence suggests that the Belgian component of EU-SILC performs relatively well at both internal and external coherence (Lusyne, 2007). The sample contains 14,329 individuals in 5,860 households, and is representative for the Belgian population living in private households.

1 The modified OECD equivalence scale gives a weight of 1.0 to the first household member aged fourteen or over; 0.5 to each additional household member aged fourteen or more and 0.3 to every member younger than fourteen. 
The model MISIM assumes full take-up of benefits and no tax evasion. As the simulations in this article basically relate to personal income taxes and social contributions, the issue of non take-up is not relevant here; moreover, means-tested benefits make up only a small fraction of social benefits in Belgium. Tax evasion may be an issue, but the possible extent of it is unknown and cannot be estimated due to lack of information. However, as documented in Verbist (2003), the Belgian personal tax system is well covered by MISIM, and outcomes are in line with administrative tax information. Consequently, MISIM based simulations can be considered sufficiently reliable first-order estimates.

In this article, only first-order effects are considered, so no account is taken of possible labour supply effects. Some microsimulation studies do model the behavioural response in terms of labour supply and find that the effects of potential second round effects are relatively limited (see e.g. Bargain and Orsini, 2007, who use EUROMOD to model the introduction of an Anglo-Saxon type of working tax credits in three European countries).

Previous microsimulation studies reveal the existence of a trade-off between the work incentive and the redistributive effects of measures aiming to 'make work pay'. While efforts targeted at low-paid workers may make perfect sense from the perspective of increasing work incentives, this does not imply that the redistributive effects are as desirable as one might want them to be. Many low-paid workers potentially affected by financial disincentives are not at the bottom of the distribution in terms of their disposable income at the household level; in many instances they are in fact relatively high up the household income distribution. Efforts to remove potential dependency traps may effectively involve redistribution to households relatively high up the income distribution. Hence, the effectiveness of the measures on both fronts crucially depends on their design (and particularly whether the measures are aimed at individuals with low earnings or in low-income households) and also on the interactions with the tax-benefit systems in place (Sutherland, 2001; Müller and Steiner, 2008; Figari, 2009).

\section{In-work poverty in Continental Europe and Belgium}

Gauging from the EU Social Inclusion Indicators database derived from EU-SILC, the extent of in-work poverty in 2008 ranges from a low of four to five per cent in Belgium and the Netherlands, to around six to eight per cent in Austria, Germany and France, and over twelve per cent in Spain, Portugal and Greece.

In-work poverty is clearly significant across the EU. It is quite clear that the extent of in-work poverty is not reflective of how widespread relatively low-paid work is, defined as $2 / 3$ of the median monthly wage. In Ireland and the United Kingdom, earnings are considerably more dispersed and relatively low-paid work more widespread (Blau and Kahn, 2008; Lucifora and Salverda, 2008). Yet, with poverty rates for workers at six per cent in Ireland and nine per 
cent in the United Kingdom, in-work poverty is not more widespread than elsewhere in Europe.

In framing effective policy responses it is essential to understand that low-paid work and inwork poverty are largely separate phenomena. Various studies have demonstrated that the overlap between low pay and poverty is weak - in the order of five to ten per cent in most industrialised economies (Nolan and Marx, 2000). This is because poor households generally do not contain an employee, whether low-paid or not, while most low-paid workers live in households with more than one earner. A crucial influence is thus the extent to which the household relies on the earnings of this low-paid worker. Particularly for low-paid women and young people, their earnings most often constitute a secondary or even tertiary source of income for the household. In some cases, accepting a low-paid job helpsto lift household income above the poverty threshold (Gardiner and Millar, 2006). Low-paid workers who are not primary earners are often reasonably high up the income distribution.

While the low-paid do still comprise a substantial proportion of the working poor, many often a majority - of the working poor are not below conventional low pay thresholds. The core of the working poor consists of workers who are sole earners and have a family to support. Even a moderately well-paid job may not suffice to meet household income needs, depending on the extent of those needs and the other sources of income available to the household.

What matters is the combined labour market position of household members. Having only one earner in the household has become a poverty risk in an era in which the average living standard, and hence the relative poverty threshold, is increasingly determined by the dual earner living standard. This helps to explain why in-work poverty is pervasive across Europe, and why its extent does not simply reflect the size of the low-wage sector. In-work poverty is more strongly associated with the prevalence of single-earnership than it is with the size of the low-paid work force, In-work poverty is thus a problem associated with a multiplicity of institutional factors (e.g. labour market regulation, child care support, tax incentives etc.) that influence a household's capacity for acquiring multiple incomes in an era in which multiple household incomes are usually required to attain a decent standard of living. Lohmann and Marx (2008), comparing the EU-15 countries, argue that these institutional factors are most favourably aligned in the Nordic countries and least favourably in the South, while the institutional constellations in the Anglo-Saxon and Continental European countries have mixed and sometimes contradictory effects.

In Belgium, the labour market and the welfare state remain to some extent geared towards the breadwinner model (Marx and Verbist, 2008b). With an implicit breadwinner bias still present in wage-setting institutions and elements of labour market regulation, the size of the lowwage labour market remains comparatively limited. Job security protection remains elaborate, derived social security rights remain substantial and the tax system supports the sole breadwinner model to some extent. At the same time, however, childcare provisions for working parents are extensive, making Belgium a case in point of what has been called 
"optional familialism", where the care-giving family is supported, but at the same time families are also given the option of being (at least partially) unburdened from childcare responsibilities (Leitner, 2005).

Table 1 shows the extent and structure of in-work poverty in Belgium. It is primarily a phenomenon affecting prime-age workers. There is no strong gender bias, with male and female workers equally affected. Workers of all education levels are confronted with in-work poverty, albeit those with lower education levels relatively more strongly. The overlap with low-pay employment is relatively limited. There is a strong association with work intensity in that full-year, full-time workers are considerably less likely to be confronted with in-work poverty than part-year, part-time workers. Particularly important is the incidence and distribution of in-work poverty across household configurations. Employed lone parents and single-earner couples with dependent children are most at risk of poverty. Single persons have a lower poverty risk, but because of their population share they constitute a significant share of poor workers. Among dual-earner households without children, in-work poverty is virtually non-existent. Yet a small but significant proportion of dual earner households with dependent children have insufficient combined earnings to live free from financial poverty. Hence, the population of workers confronted with poverty is a heterogeneous one, which is clearly important when it comes to framing policies. 
Table 1. Profile of the working poor in Belgium, 2005 (Poverty line at $60 \%$ of median equivalent income).

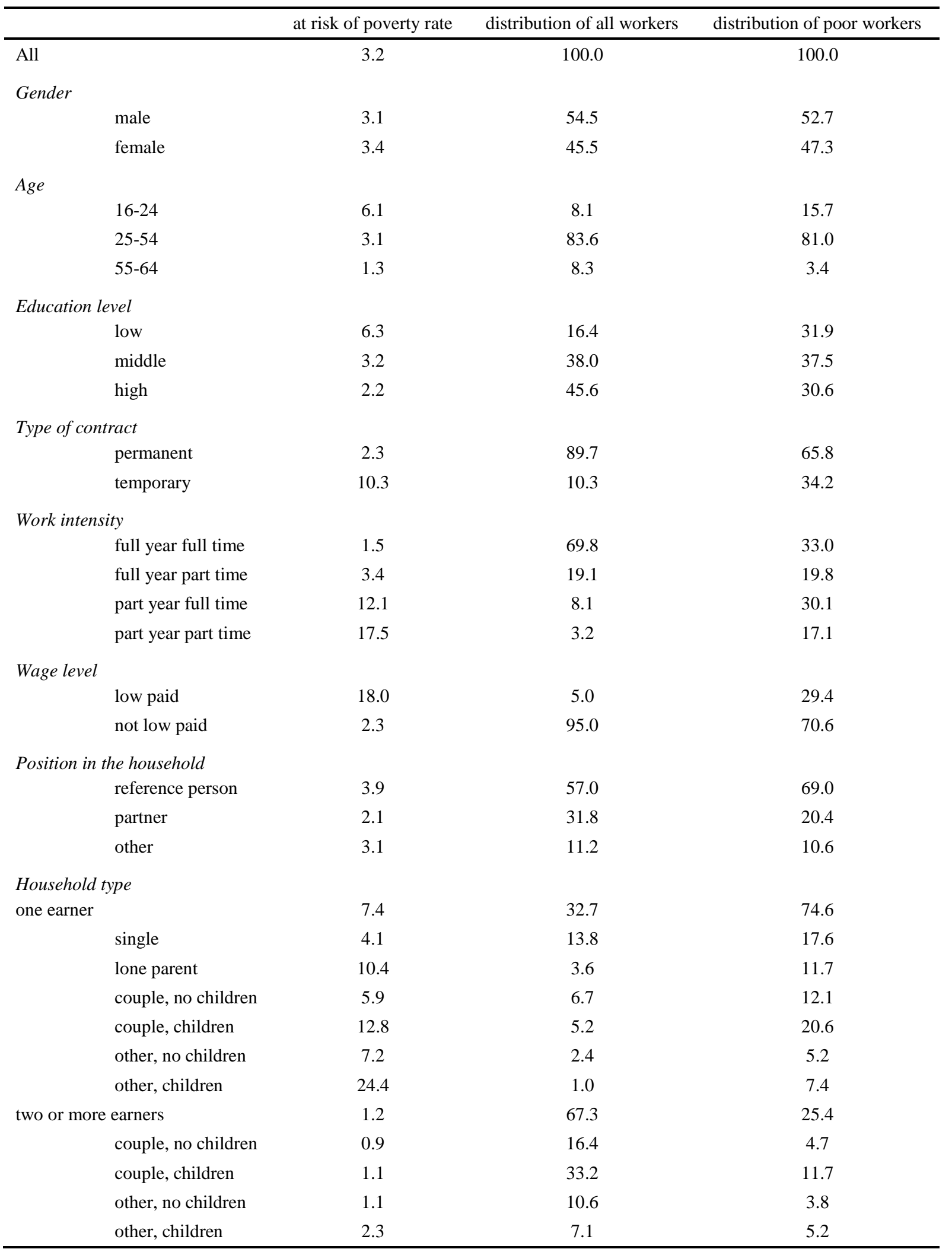

Note: Workers are defined as those whose main activity status was 'in work' (full time or part time) for at least one month during the reference year and who earned a strictly positive income from employment, excluding self-employment. Low pay is defined as earning less than $2 / 3$ of the median gross hourly wage for all employees.

Source: own calculations on the basis of SILC2006. 


\section{Increasing minimum wages}

\section{Minimum wages in general}

The number of European countries with a national wage, set by law or through collective bargaining at the national level, has increased over the past two decades (VaughanWhitehead, 2010). The early 1990s saw the introduction of minimum wages in the formerly Communist countries that are now part of the European Union. The United Kingdom introduced a national minimum wage in 1999, Ireland introduced one a year later and Austria in 2009. In 2010, nineteen Member States of the European Union had a national minimum wage, set by government, often in cooperation with or on the advice of the social partners, or by the social partners themselves in a national agreement. ${ }^{2}$ In a number of countries where no national minimum wage exists, like in Germany and the Nordic countries, workers are protected by collective agreements set at the industry or firm level. These vary considerably in coverage and in level.

Both EUROSTAT and OECD data show increases in real minimum wages in all but a few EU countries. The most significant real term increases have by and large occurred in the EU12 countries. However, these real increases translate into a more diverse picture if it comes to relative trends. Mostly on the basis of Eurostat data complemented with national sources, Vaughan-Whitehead (2010) finds, for the period 1995-2007, declines relative to average wages in seven out of twenty EU countries included in the study, and relative rises elsewhere. Over a shorter period (2000-2005), the OECD finds a similarly mixed picture. Less is known about actual coverage and enforcement of minimum wages (Immervoll, 2007).

Do higher minimum wages still have much to offer as a strategy for tackling in-work poverty? The argument that minimum wages destroy jobs or stifle job growth is as old as the notion of the minimum wage itself, but it is also now argued that they have become a particularly ineffective if not counter-productive policy instrument in the fight against poverty due to the combined impact of the demand shift against the less-skilled and the demise of the breadwinner model (Iversen and Wren, 1998; Esping-Andersen et al., 2002). Female employment rates remain comparatively low in many European countries, and this could be partly because institutionally compressed wages limit the expansion of suitable employment. This is not the place to review the extensive literature on the employment effects of minimum wages and wage-setting institutions but research generally shows that the minimum wage floors as they actually exist tend to have limited demonstrable effects on employment, although particular groups like young people or women may be more substantially affected (Dolado et al., 1996; 2000; OECD, 1998; 2004; Kenworthy, 2004).

2 The EU countries with a national minimum wage, set by government of by a generally binding collective agreement include: Austria, Belgium, Spain, Estonia, Greece, France, Hungary, Ireland, Latvia, Lithuania, Luxembourg, Malta, the Netherlands, Poland, Portugal, Slovakia, Slovenia, Czech Republic and the United Kingdom.. 
A potentially more powerful argument against employing minimum wages or equivalent strategies as a strategy against in-work poverty is that because of the very limited overlap between low pay and poverty, any policy aimed at improving the earnings of the low-paid will directly benefit only a minority of poor households (Nolan and Marx, 2000). Studies suggest that even in those cases where the overlap between low pay and household poverty is the greatest, as is the case in the United States, increases in the minimum wage have a relatively limited impact on poverty or income inequality and a substantial spill-over to the non-poor (see, for example, Horrigan and Mincey 1993; Neumark and Wascher, 1997; Formby et al., 2005; 2010). Similarly, Gosling (1996) and Sutherland (2001) found the potential poverty-reducing effect of the national minimum wage in the UK context to be very small.

\section{Wage-setting institutions and minimum wage protection in Belgium}

Wage setting in Belgium is a matter in which unions and employers have a large degree of autonomy. Although an initial round of bargaining at the national level sets the parameters every two years, actual wage bargaining takes place at the industry level, where collective agreements are negotiated in over one hundred parity commissions, some covering specific subsectors with only a few hundred workers. Another notable feature is Belgium's automatic wage indexation system, which guarantees that wages are automatically adjusted to price increases. There is no statutory minimum wage in Belgium, but there is a nationwide, collectively agreed-upon minimum wage. This "headline" minimum wage serves more of a benchmark purpose than anything else: it constitutes the absolute bottom line of the wage structure. "Real" minimum wages (i.e., pay scales for the youngest, least qualified and least experienced workers) are negotiated at the industry level. These tend to be considerably higher than the nationwide minimum wage. According to OECD calculations, the gross earnings of a full-time Belgian minimum-wage worker amounted to 40 per cent of the average European gross wage in 2005, compared to 35 per cent for the United Kingdom (Immervoll, 2007). Also according to OECD data, and indicating that effective wage floors are even higher comparatively speaking, the incidence of low-paid work amounted to around six per cent of full-time workers versus 21 per cent in the United Kingdom. ${ }^{3}$ With such a low incidence of low-paid work among full-time workers, Belgium stands out as the country with just about the most compressed wage distribution at the lower end of the spectrum in the OECD area.

\section{The effects of minimum wages on poverty}

Despite its relatively high level, the minimum wage is insufficient to guarantee a poverty-free existence. Table 2 compares the gross minimum wage and net income at minimum wage level to the 60 per cent of median equivalent income poverty threshold, for various household

\footnotetext{
3 The incidence of low pay refers to the share of workers earning less than two-thirds of median earnings.
} 
types. The gross minimum wage is only sufficient to keep a single person out of poverty. It is insufficient for all other household types, especially when there are dependent children.

Table 2. Comparison of the monthly minimum wage for full-time workers (MW) levels relative to the poverty line, one earner households, Belgium 2005.

\begin{tabular}{lccc}
\hline & Gross MW (1) & Net income at MW (2) & 60\% poverty line \\
\hline 1 adult, no children & 1161 & 951 & 828 \\
2 adults, no children & 1161 & 1072 & 1242 \\
1 adult, 2 children & 1161 & 1034 & 1324 \\
2 adults, 2 children & 1161 & 1114 & 1738 \\
\hline
\end{tabular}

(1) gross MW = legal MW (22 years old employee) without holiday pay and end-of-year premium

(2) net income at MW = gross MW - social security contributions + work bonus - tax prepayment

The essential A key factor here is that over the past decades, average living standards, and hence relative poverty thresholds, have been pushed up not only by real wage growth but also by the proliferation of dual earnership. Consequently, the minimum wage has had great difficulty keeping pace with rising living standards. The increases in the minimum wage required to keep a sole breadwinner household with children relying on it above the poverty threshold would have had to significantly exceed the rise in average wages. Consequently, the increases in the minimum wage required to eliminate in-work poverty in most European welfare states are now quite substantial.

Using microsimulation, we evaluate the distributional and poverty-reducing impact of some very substantial minimum wage increases. First, we simulate a scenario where all workers are paid at least the current minimum wage, in order to rule out possible effects of undeclared employment or mismatches between reported values for income and working hours. Then three alternative scenarios are simulated: the minimum wage is lifted to 110,120 and 130 per cent of its current level. For each person employed at a wage lower than the respective threshold, gross employment income is brought up to the level where all hours worked are remunerated at the higher hourly wage. The microsimulation model MISIM allows calculating the resulting net income, taking into account the features of the Belgian taxbenefit system, such as eligibility for wage subsidies or tax credits, and the progressive structure of income taxation. This means that first-round effects are included, while secondround effects that may occur following the introduction of an elevated minimum wage are not accounted for. ${ }^{4}$ The effect of the minimum wage increases on the relative poverty threshold is taken into account.

Possible effects might include an adjustment of the entire wage structure to the new benchmark, or the pressure of increased labour costs on employment rates. 
Figure 1. Average gain in equivalent household income for different minimum wage increase scenarios; average over all individuals (bars, left axis) and percentage of individuals living in a beneficiary household (markers, right axis) by decile, Belgium 2005.

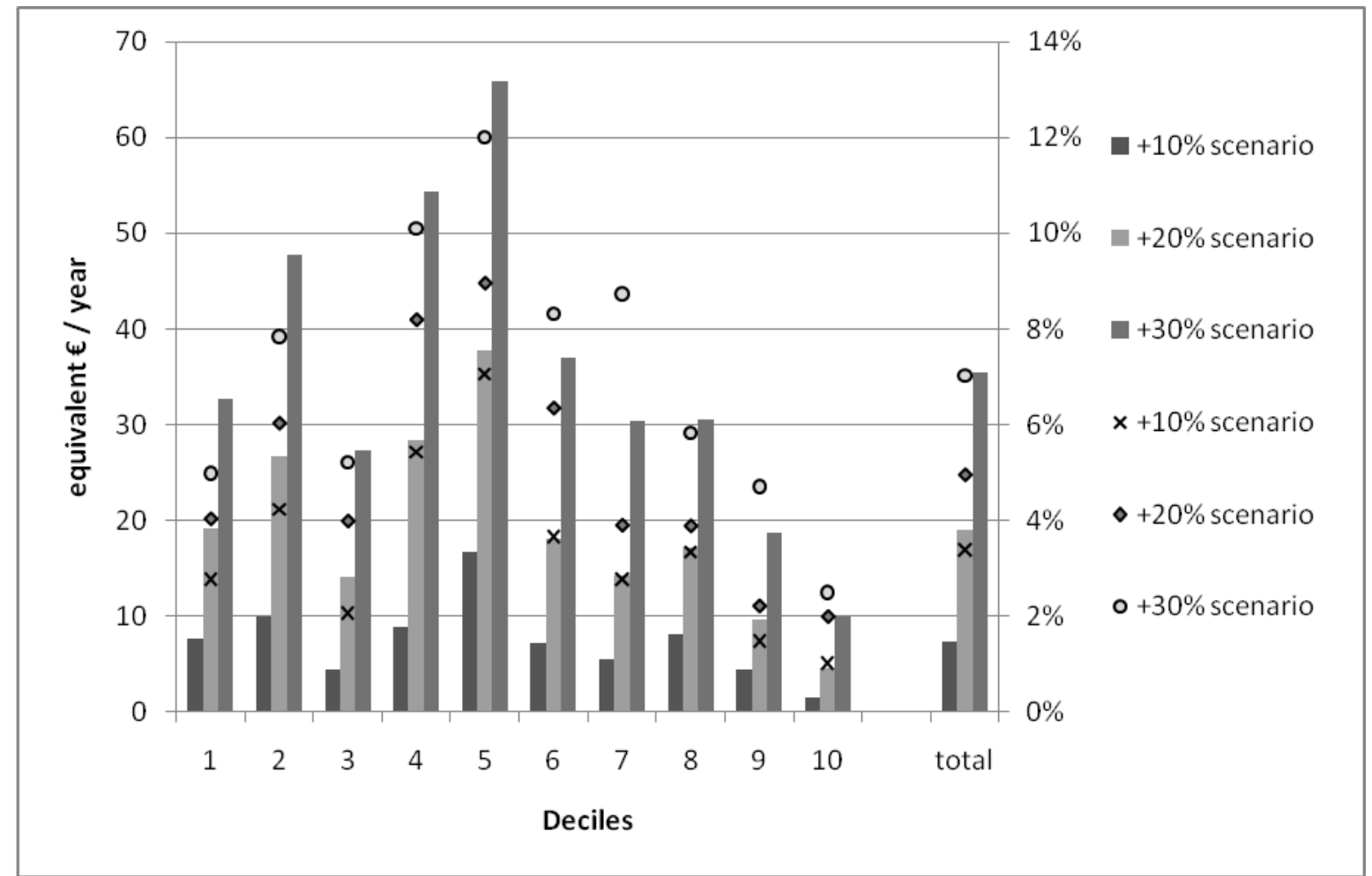

Source: own calculations on the basis of MISIM and SILC2006.

Table 3. Poverty impact of raising minimum wages to $110 \%, 120 \%$ and $130 \%$ of the current level, Belgium 2005 (Poverty line at $60 \%$ of median equivalent income, recalculated for each scenario).

\begin{tabular}{|c|c|c|c|c|c|}
\hline & Baseline & $\begin{array}{c}100 \% \text { at minimum } \\
\text { wage }\end{array}$ & $\begin{array}{c}\text { Minimum } \\
\text { wage }+10 \%\end{array}$ & $\begin{array}{c}\text { Minimum } \\
\text { wage }+20 \%\end{array}$ & $\begin{array}{c}\text { Minimum } \\
\text { wage }+30 \%\end{array}$ \\
\hline $\begin{array}{l}\text { Poverty line (expressed as a \% of } \\
\text { baseline) }\end{array}$ & 100 & 100 & 100 & 101 & 101 \\
\hline All individuals at active age & 12.41 & 12.36 & 12.29 & 12.42 & 12.48 \\
\hline \multicolumn{6}{|l|}{ Employees } \\
\hline all & 3.25 & 3.10 & 3.03 & 3.06 & 3.00 \\
\hline full time & 2.86 & 2.74 & 2.65 & 2.66 & 2.62 \\
\hline part time & 4.72 & 4.45 & 4.44 & 4.46 & 4.39 \\
\hline full time 12 months & 1.52 & 1.41 & 1.38 & 1.44 & 1.40 \\
\hline Children & 15.10 & 14.97 & 14.82 & 15.10 & 15.10 \\
\hline
\end{tabular}

Note: Employees are defined as those whose main activity status was 'in work' (full time or part time) for at least one month during the reference year and who earned a strictly positive income from employment, excluding self-employment. Full-time employees are those who have spent at least one month in full-time employment during the reference year and a larger number of months full-time than part-time, part-time employees have worked at least one month in part-time employment and a larger number of months part-time than full-time. Children are defined as all individuals aged 16 or younger.

Source: own calculations on the basis of MISIM and SILC2006. 
Figure 1 presents the average gain in equivalent household income resulting from each of the three alternative scenarios in comparison to the baseline scenario (where every working individual earns at least the minimum hourly wage). The bars express the averages over the total population, while the markers show the percentage of individuals living in a household that benefits from the policy measure.

The concentration of extra income is highest in the middle of the income distribution: average gains are highest in the fourth and fifth decile (left axis). This distribution is largely driven by the proportion of beneficiaries per decile (right axis). Only 3 (+10\%-scenario) to $5(+30 \%$ scenario) per cent of individuals situated in the first decile live in a household with a worker benefiting from the wage increase. The net gain for those who actually benefit from the respective measures is comparable or even higher in the lowest deciles than for those higher up the income distribution. But because relatively few workers are to be found in the lower deciles, the average gain is higher towards the middle of the household income distribution. This distributional pattern points to the marginal impact of these measures in terms of poverty reduction (see Table 3). Persons at risk of poverty are situated in the lowest deciles, where the percentage of gainers remains relatively limited. At the same time, about 70 per cent of the employees at risk of poverty are not low-paid which means they are not benefiting from a minimum wage increase.

About $3(+10 \%$-scenario) to $6.5(+30 \%$-scenario $)$ per cent of Belgian employees would benefit from a net nominal gain in disposable income of just over $€ 1500$ per year on average over the different scenarios. In gross terms, this corresponds to a rise of about $€ 2600$ per year. The increase in labour costs for the employer would exceed this amount by a substantial margin because of the additional employer social insurance contributions ${ }^{5}$. Note that this is yet another reason why the policy option of raising minimum wages is particularly constrained in many Continental European countries - non-wage costs in the form of additional social security contributions by employers are significant. According to OECD calculations for 2005, payroll taxes and employer contributions at minimum wage level amounted to around fifteen to seventeen per cent in Belgium, France and the Netherlands, and to around 30 per cent or more in Spain, Italy and Greece (Immervoll, 2007). By contrast, in Ireland and Britain the additional cost to employers at minimum wage level was around seven to eight per cent.

These calculations for Belgium suggest that a minimum wage increase would come at a substantial additional cost to employers, with a very limited direct impact on poverty and with the bulk of the gains going to middle income families. Hence we can safely conclude that raising minimum wages as an isolated measure is relatively ineffective and cost-inefficient as a way to reduce poverty among workers.

5 Assuming that the cost it is not shifted to the worker as afurther round effect. 


\section{Reducing social security contributions and taxes on low wages}

\section{The taxation of low wages}

OECD tax calculations for 2005 (Immervoll, 2007) show that the average tax rate on full-time minimum wages is considerable in most Continental European countries. Personal income taxes and employees social contributions amount to 18.8 per cent in Belgium, 17.6 per cent in France, and even 23.8 per cent in the Netherlands. For Ireland and the United Kingdom, the figures are 3.8 per cent and 11 per cent.

These high levels indicate that in many countries there is still substantial scope for improving the income position of low-wage households through cuts in employee social contributions and personal income taxes. Many countries have effectively introduced reductions of employees' social contributions on low wages, thus increasing the income progressivity of social contributions and taxes (Immervoll, 2007). The prime objective here, however, has not been to alleviate in-work poverty but to increase work incentives, particularly the net pay-off to making the transition from dependence on a social assistance or unemployment benefit to a low-paid job. The question we are interested in is whether such reductions also help in reducing or preventing in-work poverty.

\section{The taxation of low wage workers in Belgium}

Belgium can be noted for its comparatively high level of taxes on wages. Belgium not only has one of the highest tax burdens on average and higher wages in the OECD area, but on low wage levels as well (Immervoll, 2007). Going back to Table 2, we see that with the gross minimum wage insufficient to guarantee a life free from financial poverty (except for single persons), taxation (personal income taxes and employee social security contributions) aggravates the situation. Over the last years, Belgium has made efforts to reduce its tax burden on wages, especially for those at the lower end of the income distribution. With the 2001 tax reform, a general tax cut was introduced along with a refundable low-wage tax credit. This tax credit, amounting at its peak in 2005 to $€ 540$ per year, was applied to individual net taxable income from employment before any family-related taxation rules were taken into account. Structural reductions of employee social insurance contributions for lowwage earners were also introduced, as well as a variety of reductions in employers' social insurance contributions. One of the more recent measures intended to increase the net wages of low-wage workers is the "Work Bonus". This was introduced in January 2005, gradually replacing the structural reductions of employee contributions and the low-wage tax credit. The employee social security contribution reduction can amount to $€ 150$ per month for a lowwage worker; it is tapered away as the wage level increases. Contrary to the low-wage tax credit, it also takes into account the employee's work intensity. In the case of people earning the lowest wages, this measure can reduce the amount of social insurance contributions payable by half. 
In the following sections we study the poverty impact of tax and social security reductions for low wages by comparing three different policy measures, namely (1) the Work Bonus, (2) the Belgian Individual Tax Credit for Low Wages, and (3) the hypothetical introduction of a UKstyle Working Tax Credit. All three scenarios are set in such a way that they require the same overall expenditure, thus making it possible to compare their poverty impact. Their design and the amounts used in the simulation to attain the budget-neutrality are summarised in Table 4 .

Table 4. Stylized overview of the design features of the three types of measures (the Work Bonus (WB), the Belgian Individual Tax Credit for Low Wages (ITC) and the UKstyle Working Tax Credit (WTC), with the amounts (in €/year) used in the simulation to realize budget neutrality when hypothetically introduced in Belgium 2005.

\begin{tabular}{|c|c|c|c|}
\hline & WB & ITC & WTC \\
\hline \multicolumn{4}{|l|}{ Design } \\
\hline income base & $\begin{array}{c}\text { net taxable income from } \\
\text { employment(1) }\end{array}$ & $\begin{array}{l}\text { net taxable income from } \\
\text { employment(1) }\end{array}$ & gross total means (2) \\
\hline $\begin{array}{l}\text { min. no. of hrs } \\
\text { worked/week }\end{array}$ & - & - & 16 or 30 \\
\hline assessment unit & individual & individual & couple (3) \\
\hline \multicolumn{4}{|l|}{ Amounts (4) } \\
\hline maximum amount & 1,920 & 610 & $\begin{array}{c}\text { single: } 2,500 \\
\text { couple or parent: } 5,000\end{array}$ \\
\hline $\begin{array}{l}\text { bonus for employment of } 30 \\
\text { or more hrs/week }\end{array}$ & - & - & 1,000 \\
\hline \multicolumn{4}{|l|}{ Phase-out (5) } \\
\hline lower limit & 18,370 & 15,000 & 8,000 \\
\hline upper limit & 24,260 & 19,500 & $\begin{array}{l}\text { Depending on the } \\
\text { maximum amount, max. } \\
23,400 \text {. }\end{array}$ \\
\hline withdrawal rate or formula & $33 \%$ & $610 * \frac{(19,500-Y)}{(19,500-15,000)}$ & $37 \%$ \\
\hline
\end{tabular}

\section{Notes:}

(1) Net taxable income from employment means after deduction of professional costs and social insurance contributions.

(2) The total means taken into account for the calculation of the tax credit include gross income from employment and selfemployment, benefit income which is taxable, pensions income, investment income and property income.

(3) This implies that the amounts presented for WB \& ITC apply on the individual level, while the amounts for the WTC relate to the couple unit.

(4) These amounts are for full time equivalents. For part time workers, the maximum amounts of the WB \& ITC are reduced according to the individual's work intensity. The WB measures uses the number of hours worked as criterion, the ITC the fraction of employment income in total taxable income.

(5) For the comparison, only the phase-out zones are outlined. In the design of the ITC, however, is also made use of a phasein zone (between limits 4,500 and 6,000 €/year).

\section{The Work Bonus and the Individual Tax Credit}

Since its introduction in 2005, the Work Bonus was repeatedly extended in scope, reaching its highest level in 2009. It is the latter version we simulate, by 'backrating' the 2009 amounts to their comparable level in 2005, using the harmonised index of consumer prices. The budgetary mass thus obtained amounts to about seven per cent of total employee social 
security contributions, a ratio that corresponds to the administrative statistics for 2009 (FOD Social Security, 2010). Figure 2 presents the distribution of the net gains in equivalent household income. Over the whole population (bars, left axis), the Work Bonus gain averages 100 equivalent Euros per year. As for the minimum wage simulation, the distribution is characterised by an almost symmetric inverted U-shape, with the highest average gains in the middle deciles. With the yearly gain per beneficiary household amounting to more or less 400 equivalent Euros per year across all deciles (increasing the beneficiary families' equivalent income from work by eight per cent on average), this shape is above all determined by the distribution of the eligible workers across the income distribution. The markers (right axis) reveal the pattern of individuals living in a family with an eligible worker. These workers are most frequently present in the middle deciles. Their salary is often a secondary income source in a household including several earners. In the highest deciles, the presence of low-paid workers is substantially smaller. These upper deciles are to a considerable extent populated by dual-earner households accumulating two salaries. In the lower deciles finally, the percentage of individuals living with an eligible worker is as low as in the upper deciles. Although about half of employees situated at the lower end of the income distribution is low-paid and eligible for the Work Bonus, these deciles are overwhelmingly populated by inactive persons, resulting in low average gains.

Figure 2. Average gain in equivalent household income due to the Work Bonus by decile, Belgium 2005.

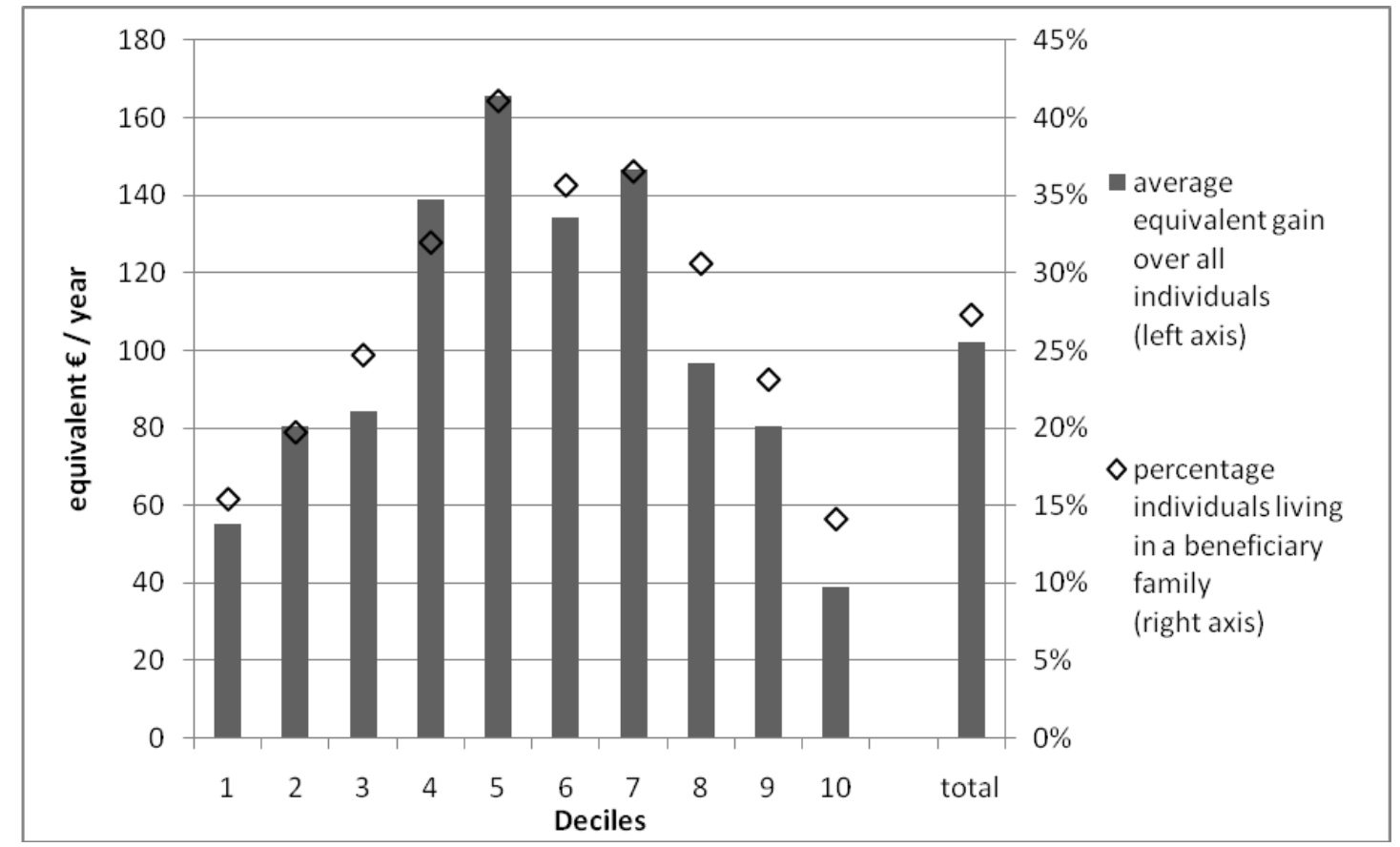

Source: own calculations on the basis of MISIM and SILC2006

Next, the Individual Tax Credit for low wages is simulated in its 2005 configuration. For the simulation, the amounts and brackets were slightly uprated in order to achieve budgetneutrality with the Work Bonus measure. The amounts used as well as a summary of the main design features can be found in Table 4. 
The distribution of the gains from the Individual Tax Credit is shown in Figure 3. It strongly peaks towards the upper middle of the income distribution, both for the averages over all individuals as over the beneficiary households only. A number of design features account for this remarkable shape. First, no account is taken of work intensity, which means that part-time workers benefit more than full-time workers, because generally their total income from employment is much lower. Second, the relative amount of the Tax Credit is reduced to the share of employment income in a person's total income. This feature makes the net gain lower for workers in the lowest deciles, who most often combine, over the time span of a tax year, income from employment with a replacement income.

Figure 3. Average gain in equivalent household income due to the Individual Tax Credit for low activity income by decile, Belgium 2005.

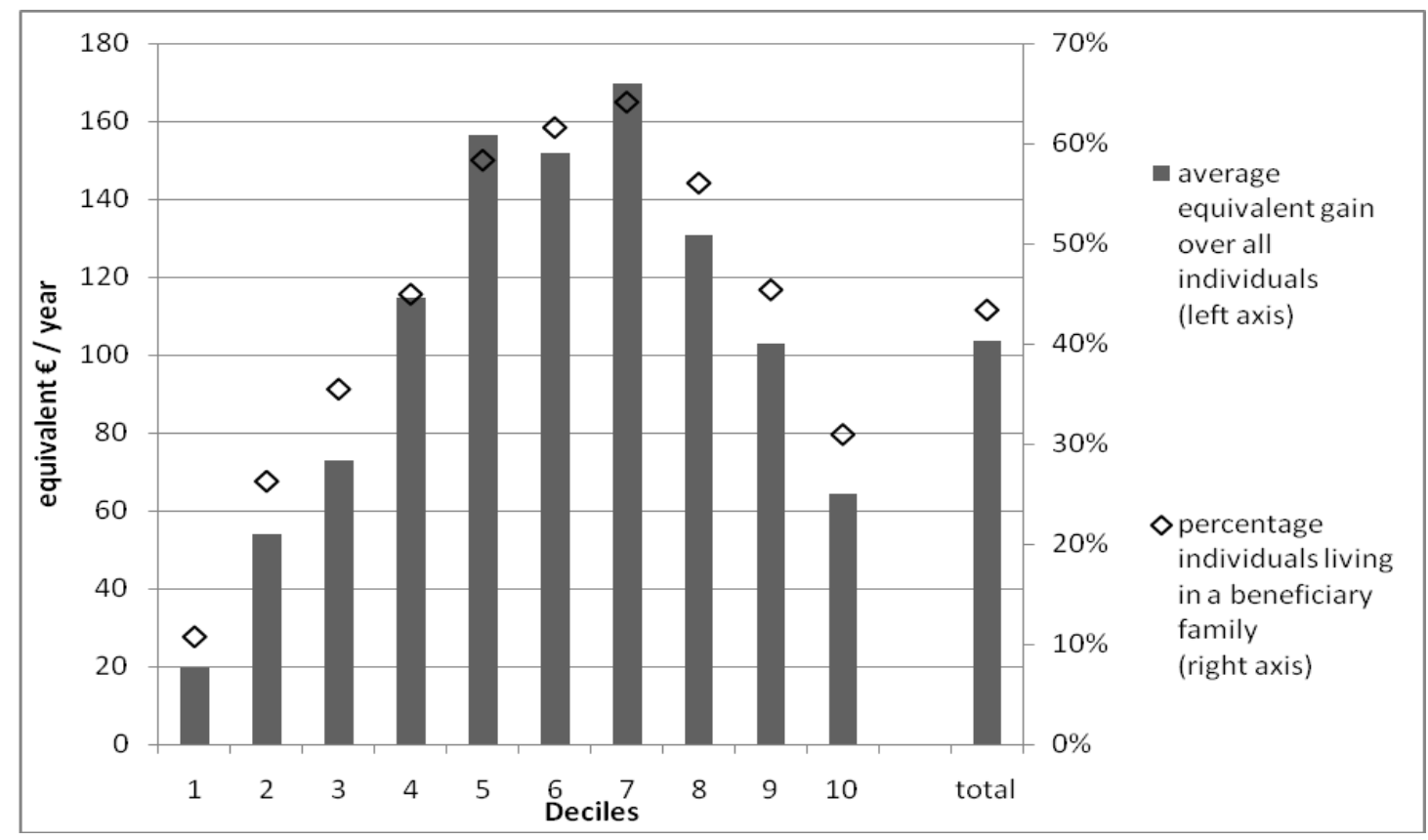

Source: own calculations on the basis of MISIM and SILC2006.

\section{The introduction of a stylised version of the UK Working Tax Credit}

Finally, and to examine the impact of targeting low-wage tax credits at households rather than individuals with low earnings, we implement the UK Working Tax Credit in the Belgian context. In the UK, this measure is part of a tax credit package that also includes the Child Tax Credit. However, we focus solely on the working tax credit, thus leaving out the childcare component, as this is already covered by existing measures in Belgium. As outlined in Table 4 , the modelled WTC is a stylised version of the UK $2005 \mathrm{WTC}^{6}$ and differs from the previous measures modelled in a number of ways. First, the WTC entails a means-test based on a much broader income concept than the earlier discussed measures. The means-test is combined with an eligibility condition requiring that at least one person is working more than

6 The degree of detail available in the data did not allow us to model all features of the measure. The disability conditions and the 50+-component of the UK WTC were therefore left out in the measure modeled. 
sixteen hours/week for a household with a dependent child, or 30 hours/week for a household without dependent children. Second, the maximum amount depends on the household situation, and differs for singles, couples and lone parents. The means-test does not differ across household types, and especially for couples, the upper limit of the phase-out seems quite low compared to the other two individual-based measures. The maximum amounts, however, are substantially higher in comparison, however.

Furthermore, families are eligible for an additional component when at least one person works more than 30 hours. The amounts and brackets of the 2005 UK WTC were adapted to the Belgian system, using the average Euro/Pound Sterling exchange rate over the year 2005 . Furthermore, all amounts were slightly uprated to equal the budgetary mass required by the two other simulated measures. Table 4 presents the exact design.

The results of this exercise are presented in Figure 4. In comparison to the other two measures, the Working Tax Credit reaches more families in the lowest deciles. The gains correspond to a rise of their equivalent income from employment of 33 per cent on average. In order to keep the budget neutral in the simulation, the taper-off thresholds are quite low and the withdrawal rates steep, which results in a very small share of eligible families, in comparison to the other two measures. Only in the lowest decile are there more individuals living in a family benefiting from this measure (about twenty per cent) than in the other scenarios (resp. fifteen and eleven per cent). However, the strict targeting also implies that the benefit mainly reaches families with a work intensity at the lower side of the spectrum, as a low-paid full-year full-time worker earns at least $€ 16,000$ on a yearly basis. ${ }^{7}$ Additionally, the steep withdrawal rate increases the risk of mobility traps. But given that the lower end of the household earnings distribution is so crowded, flattening the phase-out zone would come at an exponential rise in costs, which can only be avoided by lowering the tax credit itself, thus at the expense of its poverty reducing effectiveness.

Earning twelve months the full-time minimum wage, plus holiday payment and Christmas bonus. 
Figure 4. Average gain in equivalent household income due to the UK Working Tax Credit implemented in Belgium 2005.

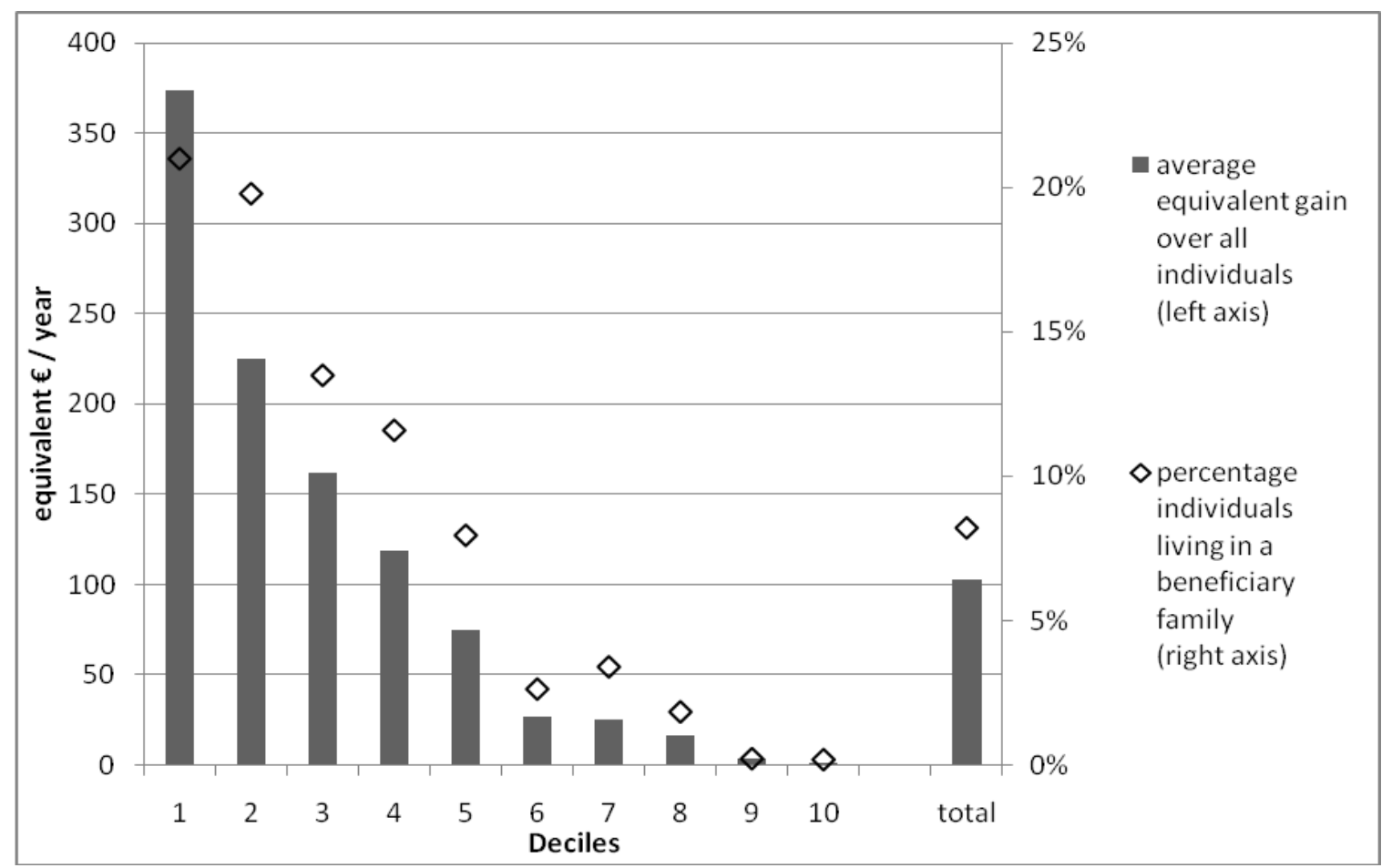

Source: own calculations on the basis of MISIM and SILC2006

\section{The poverty impact of the three alternatives}

As shown in Table 5, the poverty impact of the three measures is quite different, despite the fact that they require a similar budgetary effort. The effects are compared to a hypothetical pre-reform scenario, with no measure in place. The Individual Tax Credit for low activity income performs worst in reducing poverty. Due to its insensitivity to a number of factors associated with in-work poverty, such as work intensity, the tax credit is mostly subsidizing part-time second earners in non-poor households. Due to the upward movement of the poverty line, the at-risk-of-poverty rate for all persons at active age as well as for children even increases somewhat.

Only a relatively small share of working-poor families is lifted out of poverty thanks to the Work Bonus, which is slightly better targeted at actual low-wage employment. Given that the reduction is in order of 0.5 percentage points or, around 13 per cent of poor employees, the effect is not unimportant, but it is not large. That said, the Work Bonus does succeed in its primary aim of reducing inactivity traps through generating higher net incomes for low-paid work. But the poverty impact is limited. Because of the weak overlap between low-paid work and household poverty, the potential impact of any measure that targets low-paid workers rather than households with low (combined) earnings, is intrinsically limited at any rate.

The implementation of a stylised version of the UK Working Tax Credit is in this respect especially interesting. The at-risk-of-poverty rate for employees drops by almost one percentage point, and at the same time the poverty rate for the whole population of active age, 
as well as for children, diminishes. With the given budget, this measure has the most efficient poverty reduction capacity. Its reach, however, remains too small to eliminate in-work poverty, at least within the budgetary constraints we impose for the purpose of making the simulated policy alternatives comparable.

Table 5. Poverty impact of the Work Bonus (WB), the Individual Tax Credit for low activity income (ITC), and the UK Working Tax Credit (WTC) implemented in Belgium, 2005 (Poverty line at $60 \%$ of median equivalent income, recalculated for each scenario)

\begin{tabular}{lcccc}
\hline & Pre-reform & with WB & with ITC & with WTC \\
\hline $\begin{array}{l}\text { Poverty line (expressed as a \% } \\
\text { of baseline) }\end{array}$ & 100 & 101 & 101 & 101 \\
$\begin{array}{l}\text { All individuals at active age } \\
\text { Employees }\end{array}$ & 12.54 & 12.53 & 12.78 & 11.69 \\
$\quad$ all & 3.48 & 3.02 & 3.39 & 2.55 \\
full time & 3.04 & 2.59 & 2.98 & 2.02 \\
$\quad$ part time & 5.15 & 4.62 & 4.94 & 4.63 \\
full time 12 months & 1.56 & 1.37 & 1.51 & 1.19 \\
Children & 15.19 & 15.24 & 15.29 & 13.67
\end{tabular}

Note: Employees are defined as those whose main activity status was 'in work' (full time or part time) for at least one month during the reference year and who earned a strictly positive income from employment, excluding self-employment. Full-time employees are those who have spent at least one month in full-time employment during the reference year and a larger number of months full-time than part-time, part-time employees have worked at least one month in part-time employment and a larger number of months part-time than full-time. Children are defined as all individuals aged 16 or younger.

Source: own calculations on the basis of MISIM and SILC2006

\section{Discussion}

We have demonstrated that, at least in Belgium, even substantially higher minimum wages would have a limited impact on in-work poverty, and at the cost of rises in labour costs and significant spill-overs to households in the middle and upper regions of the income distribution. Moreover, given that in the recent past median living standards and hence relative poverty thresholds have been pushed up, not only by rising wages but also by the proliferation of dual earnership, the increases in minimum wages required to keep workers solely relying on it above the poverty threshold are by now so substantial that they are hardly conceivable. Yet minimum wages still constitute the foundation of minimum income protection for workers. They do not have a budgetary cost, as long they do not destroy jobs and cause people to become dependent on benefits. There is no hard empirical evidence that this is the case at currently prevailing levels but such effects cannot be excluded at the levels we have simulated. Minimum wages do increase the consumer cost of certain products or services, but here it is useful to keep in mind that often this entails a redistribution between 
relatively highly paid consumers of services to relatively lower-paid providers (Freeman, 1996). Moreover, in an encompassing anti-poverty strategy, minimum wages can play a crucial role in dampening the possible wage erosion effects of in-work benefits and tax credits. This points to the importance of maintaining minimum wages and making sure that these keep pace with average wage growth

Reduced social security contributions and well-targeted individual tax credits increase the net pay of low-paid workers, but since most of them do not live in a household with a combined disposable income below the poverty line, the impact on poverty is again very limited. There are other considerations. A further shift from proportional to progressive contributions clashes with the insurance rationale of the Bismarckian systems prevalent in Continental Europe. This implies that the approach of reducing employees' contributions and deviating further from the equivalence principle has its limits.

The fundamental problem with both policy options from a poverty reduction viewpoint is that they are targeted at low-paid workers, not households with insufficient combined earnings. What then about tax relief for households rather than individuals on low earnings? As we have demonstrated for Belgium, in order to be effective as an anti-poverty device, such tax measures need to be strongly targeted. But strong targeting at households with low earnings is bound to create mobility traps. These can be avoided if taper-off rates are sufficiently flat, but that comes at a very considerable cost given that the lower end of the household earnings distribution is so densely populated in most Continental European countries. This cost can only be avoided by making the amount of the tax credit itself smaller, but in that case the antipoverty effect is reduced. In addition, from the perspective of horizontal equity and public support for the system, there are probably limits to strongly targeted tax measures.

Finally, there are policy options that do not seek to target specific segments among the poor. Universal child benefits, for example, have an immediate impact on poverty - both among those who depend on earnings and those on replacement benefits - without adversely affecting work incentives. This is important given that there is a very significant overlap between child poverty and in-work poverty. Corak et al. (2005) show that the best performing countries in terms of poverty reduction tend to have systems of universal child benefits and tax concessions that are not particularly strongly targeted at low-income children. Yet within universal systems there still is scope for targeting resources proportionally more at the poorest. Together with policies that facilitate and support dual earnership, particularly the employment of carers, such universal benefits are bound to constitute a key component of any effective policy package to tackle in-work poverty. 


\section{References}

Andre $\beta$, H.J. and Lohmann, H. (2008), The Working Poor in Europe. London: Edward Elgar.

Bargain, O. and Orsini, K. (2007), 'Beans for breakfast? How exportable is the British workfare model?', in: O. Bargain (ed.), Microsimulation in Action. Policy Analysis in Europe using EUROMOD. Research in Labour Economics, vol. 25, Oxford: Elsevier.

Blau, F. and Kahn, L. (2008), 'Inequality and earnings distribution', in: W. Salverda, B. Nolan, T. Smeeding (eds.), Oxford Handbook of Economic Inequality. Oxford: Oxford University Press.

Brewer, M., Duncan, A., Shephard, A. and Suarez, M.J. (2006), 'Did working families' tax credit work? The impact of in-work support on labour supply in Great Britain', Labour Economics, 13: 6, 699-720.

Corak, M., Lietz, C. and Sutherland, H. (2005), 'The impact of tax and transfer systems on children in the European Union', IZA Discussion Paper 1589.

Dolado, J., Kramarz, F., Machin, S., Manning, A., Margolis, D. and Teulings, K. (1996), 'The economic impact of minimum wages in Europe', Economic Policy, 11: 23, 319-372.

Dolado, J., Felgueroso, F. and Jimeno J. (2000), 'The role of the minimum wage in the welfare state: an appraisal', IZA Discussion Paper 152.

Eissa, N. and Hoynes H. (2004), 'Taxes and the labor market participation of married couples: the Earned Income Tax Credit', Journal of Public Economics, 88: 9-10, 1931-1958.

Esping-Andersen, G., Gallie, D., Hemerijck, A. and Myles, J. (2002), Why We Need a New Welfare State. Oxford: Oxford University Press.

Eurofound (2010), Working Poor in Europe. Dublin: Eurofound.

Figari, F. (2009), 'Can in-work benefits improve social inclusion in the Southern European countries?', EUROMOD Working Paper EM4/09, ISER, University of Essex.

FOD Social Security (2010), Vademecum van de financiële en statistische gegevens over de sociale bescherming in België. Brussel: Directie-generaal Beleidsondersteuning en Directie-generaal Sociaal Beleid - Federale Overheidsdienst Sociale Zekerheid.

Formby, J., Bishop, J. and Kim, H. (2005), Minimum Wages and Poverty: An Evaluation of Alternatives. Amsterdam: Elsevier.

Formby, J., Bishop, J. and Kim, H. (2010), What's best at reducing poverty? An examination of the effectiveness of the 2007 minimum wage increase. Washington DC: Employment Policies Institute.

Freeman, R. (1996), 'The minimum wage as a redistributive tool', Economic Journal, 106: 436, 639-649 and 842-849.

Gardiner, K. and Millar, J. (2006), 'How low-paid employees avoid poverty: an analysis by family type and household structure', Journal of Social Policy, 35, 351-369.

Gosling, A. (1996), 'Minimum wages: possible effects on the income distribution', Fiscal Studies, 17: 4, 31-48.

Hauser, R. (2008), 'Problems of the German contribution to EU-SILC - a research perspective, comparing EU-SILC, Microcensus and SOEP', SOEPpapers 86, DIW Berlin. 
Horrigan, M. and Mincey, R. (1993), 'The minimum wage and earnings and income inequality', in: S. Danziger and P. Gottschalk (eds.), Uneven Tides: Rising Inequality in America. New York: Russell Sage Foundation, 251-275.

Hotz, V.J. and Scholz, J.K. (2003), 'The Earned Income Tax Credit', in: R. Moffit (ed.), Means-tested Transfer Programs in the U.S., Chicago: University of Chicago Press, 141-198.

Immervoll, H. (2007), 'Minimum wages, minimum labour costs and the tax treatment of lowwage employment', OECD Social, Employment and Migration Working Papers 46, Paris: OECD.

Iversen, T. and Wren, A. (1998), 'Equality, employment and budgetary restraint, the trilemma of the service economy', World Politics, 50: 4, 507-546.

Kenworthy, L. (2004), Egalitarian Capitalism? Jobs, Incomes and Inequality in Affluent Countries. New York: Russell Sage Foundation.

Kenworthy, L. (2011), Progress for the Poor. Oxford: Oxford University Press.

Leitner, S. (2005), 'Conservative familialism reconsidered: the case of Belgium', Acta Politica, 40: 419-439.

Lohmann, H. and Marx, I. (2008), 'The different faces of in-work poverty across welfare state regimes', in: H.J. Andre $\beta$ and H. Lohmann (eds.), The Working Poor in Europe. London: Edward Elgar.

Lucifora, C. and Salverda, W. (2008), 'Low pay', in: W. Salverda, B. Nolan, T. Smeeding (eds.), Oxford Handbook of Economic Inequality. Oxford: Oxford University Press.

Lusyne, P. (2007), Een analyse naar de coherentie van de resultaten van de EU-SILC enquête. Brussel: ADSEI - Federale Overheidsdienst Economie.

Marx, I. and Verbist, G. (2008a), 'Combating in-work poverty in Continental Europe: the policy options assessed', in: H.J. Andre $\beta$ and H. Lohmann (eds.), The Working Poor in Europe. London: Edward Elgar.

Marx, I. and Verbist G. (2008b), 'When famialism fails: in-work poverty in Belgium', in: H.J. Andre $\beta$ and H. Lohmann (eds.), The Working Poor in Europe. London: Edward Elgar.

Müller, K.-U. and Steiner, V. (2008), Would a legal minimum wage reduce poverty? A microsimulation study for Germany. Berlin: DIW Discussion Paper 791.

Neumark, D. and Wascher, W. (1997), 'Do minimum wages fight poverty?', Working Paper 6127, Cambridge: National Bureau of Economic Research.

Nolan, B. and Marx, I. (2000), 'Low pay and household poverty', in: M. Gregory et al. (eds.), Labour Market Inequalities: Problems and Policies of Low-wage Employment in International Perspective. Oxford: Oxford University Press.

OECD (1998), Employment Outlook. Paris: Organisation for Economic Co-operation and Development.

OECD (2004), Employment Outlook. Paris: Organisation for Economic Co-operation and Development.

OECD (2009), Employment Outlook. Paris: Organisation for Economic Co-operation and Development.

OECD (2010), Employment Outlook. Paris: Organisation for Economic Co-operation and Development. 
Palier, B. (2010), The Politics of Reform in Bismarckian Welfare States. Amsterdam: Amsterdam University Press.

Streeck, W. (2009), Reforming Capitalism: Institutional Change in the German Political Economy. Oxford: Oxford University Press.

Sutherland, H. (2001), 'The national minimum wage and in-work poverty', DAE Working Papers MU0102, University of Cambridge.

Vaughan-Whitehead, D. (2010), The Minimum Wage Revisited in the Enlarged EU. Cheltenham: Edward Elgar.

Verbist, G. (2003), 'MISIM, een microsimulatiemodel voor personenbelasting en sociale zekerheid', Maandschrift Economie, 67, 451-473. 